\title{
FAKTOR PEMBERIAN HIBAH MENURUT PERSPEKTIF PENTADBIR TANAH (Factors of Granting Hibah From the Land Administration's Perspective)
}

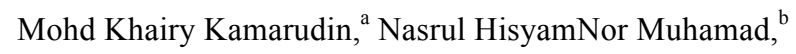 \\ Fakulti Keusahawanan dan perniagaan Universiti Malaysia Kelantan, ${ }^{a}$ \\ Fakulti Tamadun Islam Universiti Teknologi Malaysia. ${ }^{b}$ \\ *Corresponding author: khairy.k@umk.edu.my
}

\begin{abstract}
Abstrak
Pemberian hibah melalui pindah milik tanah merupakan amalan yang sering diaplikasikan oleh masyarakat Islam di Malaysia. Pindah milik tanah ini boleh dilakukan di Pejabat Tanah dengan melalui Borang 14A. Namun begitu, terdapat pertikaian dalam kalangan waris dari sudut keadilan pembahagian hibah sehingga banyak kes-kes berkaitan kesahan dan penarikan balik hibah di Mahkamah. Maka timbul persoalan, bagaimana pemilihan penerima hibah oleh pemberi hibah bagi harta mereka. Oleh yang demikian, kajian ini dijalankan untuk mengenal pasti amalan pindah milik tanah secara hibah dalam kalangan ibu bapa menurut perspektif Pentadbir Tanah. Kajian ini menggunakan pendekatan kualitatif di mana temu bual separa berstruktur dengan Pentadbir Tanah dijalankan. Hasil kajian ini mendapati, ibu bapa menghibahkan tanah miliknya kepada anak-anak kerana mengelakkan harta tersebut diagihkan mengikut hukum faraid dan membantu anak-anak disebabkan kekangan ekonomi yang dimilikinya.
\end{abstract}

Kata kunci: Hibah; Pindah Milik; Motif Pemberian

\begin{abstract}
Hibah through transfer the ownership of land is a regular practice among Muslims in Malaysia. Transfer the ownership of land can be completed in the Land Office by using Form 14A. However, there are many disagreements among the heirs towards the equality of transfer ownership as many cases concerning the validity and the withdrawal of the hibah in court. So the question arises, how the selection of beneficiaries by the grantors for their property. Therefore, the aim of this study is to identify transfer of the land ownership, according to the Land Administrator perspective. This study applies a qualitative approach in which semi-structured interviews with Land Administrator was conducted. The results indicates that parents transfer his/her land to the children as to avoid property is distributed according to the law of inheritance and help their children due to economic constraints.
\end{abstract}

Keyword(s): Hibah; Transfer ownership; Giving motive 


\subsection{PENDAHULUAN}

Masalah harta pusaka yang terbeku merupakan isu yang sangat meruncing. Sehingga hari ini dianggarkan sebanyak RM60 bilion harta yang tidak dituntut (Aziz, 2016; "Harta pusaka tidak dituntut mencecah angka RM60 bilion," 2016). Terdapat banyak faktor yang menyumbang kepada masalah ini antaranya sikap pengabaian waris terhadap proses tuntutan disebabkan kurangnya pengetahuan tentang proses tuntutan pusaka dan bayaran yang tinggi untuk menuntut pusaka (Noordin, Shuib, Zainol, Azam, \& Adil, 2012). Hal ini menyebabkan kesukaran waris untuk membangunkan harta tersebut bagi tujuan ekonomi. Oleh yang demikian, terdapat penyelidik mencadangkan supaya perancangan harta semasa hidup seperti pemberian hibah perlu dilakukan (contohnya Abdul Rashid \& Ahmad, 2013; Hasbullah \& Daud, 2015; Nor Muhamad \& Mat Hussain, 2014).

Pemberian hibah merupakan salah satu instrumen perancangan pusaka Islam yang berpotensi untuk mengelakkan harta pusaka yang ditinggalkan tidak diurus dan tidak dituntut oleh waris (Abdul Rashid, Hassan, \& Yaakub, 2014; Awang \& Abd Rahman, 2014). Hibah secara umumnya dapat didefinisikan sebagai pemberian semasa hayat daripada pemilik harta kepada penerima tanpa sebarang balasan. Pemberian hibah ini hukumnya adalah sunat berdasarkan firman Allah S.W.T dalam Surah Al-Baqarah, ayat 177 yang bermaksud:

\section{“...... dan mendermanya seseorang akan hartanya sedang ia menyayangi, - kepada kaum kerabat ....”}

Pemberian hibah perlulah semasa hayat pemberi hibah untuk membezakannya dengan wasiat. Wasiat merupakan pemberian yang berlaku hanya selepas kematian pemilik harta. Tambahan lagi, wasiat hanya tertakluk kepada 1/3 daripada keseluruhan harta dan hanya boleh diberikan kepada bukan waris (Md Razak et al., 2015; Noordin et al., 2012). Hal ini menyebabkan wasiat tidak menjadi pilihan utama pemilik harta kerana fungsinya yang terhad berbanding hibah. Hibah boleh diberikan kepada sesiapa sahaja dan tidak tertakluk kepada jumlah (Abdul Rashid \& Ahmad, 2013).

Namun begitu, terdapat kekangan dalam melicinkan pelaksanaan hibah ini iaitu ketiadaan undangundang khusus berkaitan pemberian hibah di peringkat Negeri dan Persekutuan (Md Razak et al., 2015; Mohd Yusof \& Ahmad, 2013). Kesannya, terdapat banyak kes-kes berkaitan hibah yang dipertikaikan di mahkamah sama ada hibah yang dibuat secara lisan mahupun bertulis. Antara kes berkaitan pemberian hibah ialah seperti Abdul Wahid Bin Dato Haji Abdul Rahim Gulam Rasool Shaik \& Yang Lain lwn Shariahbibi Binti Ibrahim Mysoory \& Yang Lain ${ }^{1}$, Tengku Hj Jaafar Tengku Muda \& Seorang Lagi lwn Kerajaan Pahang 2 , Muhammad b. Awang \& Yang Lain lwn Awang b. Deraman \& Yang Lain ${ }^{3}$, Ibrahim Yusuff lwn Eshah Hj. Ishak \& Yang Lain ${ }^{4}$ dan Pengesahan Hibah Siti Noor Aseera bt. Awang ${ }^{5}$. Antara pertikaiannya ialah waris-waris tidak mempersetujui kandungan dokumen hibah, pertikaian terhadap kesahan hibah dan penarikan balik hibah (Mohd Yusof \& Ahmad, 2013). Dari sudut undang-undang sivil, amalan pemberian hibah ini diiktiraf sebagai salah satu daripada transaksi yang mendapat jaminan perlindungan di bawah Kanun Tanah Negara 1965. Pemberi hibah hanya perlu mengisi Borang 14A di Pejabat Tanah, akusaksi, pengeseteman dan bayaran pendaftaran. Malah amalan proses pindah milik di bawah kanun ini tidak melibatkan unsur-unsur yang dilarang di dalam Islam. Perkara ini diperkukuhkan

\footnotetext{
${ }^{1}[1986] 2$ MLJ 211

${ }^{2}[1987] 2$ MLJ 74

${ }^{3}[2001] 2$ JH 165

${ }^{4}[2006] 2$ JH 158

5 [2007] 1 JH 119).
} 
lagi dari sudut pemilikan iaitu berdasarkan Seksyen 340, Kanun Tanah Negara yang menjelaskan pendaftaran pemilikan telah memberikan hak milik atau kepentingan yang tidak boleh disangkal. Akibatnya, pemberi hibah tidak boleh menarik balik hibah yang telah diberikan (Abdul Rashid \& Yaakub, 2010).

Dari sudut lain, walaupun wujudnya pertikaian dalam kalangan waris dan ketiadaan undang-undang khusus berkaitan hibah, pemberian hibah masih lagi menjadi pilihan ibu bapa untuk menghibahkan tanah atau rumah kepada anak-anaknya. Oleh yang demikian, kajian ini dijalankan untuk mengenal pasti amalan pemberian hibah hartanah ibu bapa kepada anak-anak dari perspektif Pentadbir Tanah. Kajian ini menggunakan pendekatan kualitatif di mana temu bual separa berstruktur dengan Pentadbir Tanah dijalankan.

Kajian ini dibahagikan kepada lima bahagian. Bahagian pertama ialah pendahuluan kajian ini yang menerangkan secara umum isu-isu yang berlaku berkaitan pemberian hibah. Bahagian kedua pula ialah sorotan kajian lepas berkaitan teori-teori pemberian hibah. Manakala bahagian ketiga menerangkan kaedah kajian ini dijalankan dan bahagian keempat merupakan dapatan kajian. Bahagian terakhir adalah perbincangan dan kesimpulan kajian ini.

\subsection{Sorotan Kajian Lepas}

Pemberian hibah daripada ibu bapa kepada anak-anak telah dibincangkan secara meluas dari sudut ekonomi dan sosial. Pemberian hibah bertindak sebagai kaedah untuk meningkatkan kehidupan seseorang individu. Namun pemberian ini kemungkinan akan meningkatkan tidak sama rataan pemberian dalam kalangan ahli waris (Raad \& Guedes, 2015). Secara umumnya, terdapat dua motif utama ibu bapa menghibahkan harta kepada anak-anak iaitu motif altruisme dan motif pertukaran (exchange). Kajiankajian lepas mendapati bahawa kedua-dua motif boleh wujud bersama (Wu \& Li, 2014) dan tiada kesepakatan motif yang mana lebih dominan (Albertini \& Radl, 2012).

Pemberian hibah yang bersifat altruistik didorong oleh moral dan kewajipan untuk membantu orang lain. Maka ibu bapa yang bersifat altruistik ini cenderung untuk membantu anak-anak mereka yang berada dalam kesusahan. Hal ini juga didorong oleh rasa ambil berat terhadap kebajikan anak-anak mereka (Albertini \& Radl, 2012; Barczyk \& Kredler, 2014; Wu \& Li, 2014). Pemberian ini boleh terjadi melalui pemberian yang berbentuk kewangan dan bukan kewangan seperti meluangkan masa bersama anak-anak atau memberikan nasihat.

Ibu bapa memberikan bantuan dari sudut kewangan untuk membeli rumah atau membiayai pendidikan mereka (Barczyk \& Kredler, 2014). Selain itu, ibu bapa yang bersifat altruistik akan dapat membantu meningkatkan kekayaan anak-anak mereka (Raad \& Guedes, 2015). Ibu bapa akan lebih cenderung untuk menghibahkan hartanya kepada anak-anak yang berpendapatan rendah. Hal ini disebabkan terdapat kebarangkalian peningkatan hibah ibu bapa kepada anak-anak disebabkan pendapatan anak-anak mereka jatuh. Tahap pendapatan juga dipengaruhi oleh taraf pendidikan seseorang individu (Scodellaro, Khlat, \& Jusot, 2012). Taraf pendidikan yang rendah juga turut mendorong ibu bapa untuk menghibahkan sebahagian besar harta mereka kepada anak tersebut (Raad \& Guedes, 2015; Wu \& Li, 2014). Maka, anak-anak yang berada di dalam kelas- pekerja (working-class) dapat meningkatkan mutu kehidupan mereka (Albertini \& Radl, 2012). Selain itu, terdapat juga kemungkinan anak-anak yang belum berkahwin, anak-anak yang sudah mempunyai anak atau anak-anak yang masih tidak bekerja, lebih memerlukan sokongan dan bantuan daripada ibu bapa berbanding anak-anak yang sudah berkahwin dan tinggal bersama dengan pasangannya atau yang sudah memiliki kerja yang tersendiri (Kalmijn, 2013).

Tujuan utama ibu bapa bersifat altruistik bagi melancarkan tahap penggunaan (level of consumption) anak-anak mereka. Ibu bapa cuba untuk menyamaratakan tahap utiliti anak-anak mereka dengan menghibahkan hartanya kepada anak-anak yang mempunyai kedudukan ekonomi yang paling rendah 
(Raad \& Guedes, 2015). Dalam erti kata yang lain, pemberian hibah kepada anak-anak bergantung pada keperluan dan keadaan ekonomi mereka (Abdul Rashid \& Ahmad, 2013; Abdul Rashid, Hassan, \& Yaakub, 2013; Abdul Rashid et al., 2014; Awang \& Abd Rahman, 2014). Motif altruisme ini juga mendorong kepada dalam ibu bapa memberikan keutamaan kepada jantina yang tertentu. Hal ini disebabkan kemungkinan tahap penggunaan anak-anak yang berlainan jantina adalah berbeza berdasarkan perspektif ibu bapa. Contohnya, kajian yang dijalankan di Korea, mendapati ibu bapa lebih banyak menghibahkan harta kepada anak lelaki (Wong, 2013).

Manakala, bagi motif pertukaran, pemberian hibah dari ibu bapa kepada anak-anak berkait rapat dengan tanggungjawab anak-anak untuk membantu ibu bapa mereka apabila sudah tua. Pemberian hibah berdasarkan motif pertukaran, ibu bapa menjangkakan mereka akan menerima apa jua balasan di masa akan datang (Wu \& Li, 2014). Balasan tersebut boleh terjadi sama dalam bentuk sumber (contohnya bantuan kewangan) atau perkhidmatan (contohnya memberikan perhatian dan menjaga ibu bapa). Pemberian hibah ini juga berdasarkan keinginan ibu bapa untuk membentuk kewajipan moral dalam kalangan anak-anak untuk membantu ibu bapa pada masa akan datang (Albertini \& Radl, 2012). Kalmijn, (2013) berpandangan ibu bapa akan lebih banyak memberikan bantuan dalam bentuk kewangan atau bukan kewangan kepada anak-anak yang mereka jangka akan memberi bantuan berbanding anak-anak yang mereka jangka kurang memberikan bantuan. Di samping itu, pemberian hibah juga merupakan dapat merangsang gelagat anak-anak untuk membantu ibu bapa (Raad \& Guedes, 2015).

Kesimpulannya, kedua-dua motif ini saling berkait rapat dengan peranan ibu bapa dan kedudukan anak-anak. Ibu bapa bertanggungjawab untuk membantu anak mereka khususnya anak-anak yang mempunyai kedudukan ekonomi yang kurang baik dan merangsang anak-anak untuk menjaga mereka apabila mereka sudah tua. Manakala, kedudukan anak-anak pula mampu mempengaruhi ibu bapa dalam memberikan hibah kepada mereka disebabkan mereka telah menjaga ibu bapa dan keadaan ekonomi mereka yang kurang baik berbanding adik-beradik mereka yang lain.

\subsection{Kaedah Penyelidikan}

Kajian dijalankan ini melalui pendekatan kualitatif di mana temu bual separa berstruktur dilakukan. Temu bual secara berstruktur dijalankan ke atas Pentadbir tanah yang bertanggungjawab dalam urusan pemindahan hak milik. Pentadbir tanah merupakan individu yang bertanggungjawab untuk menguruskan hal-hal yang berkaitan dengan pindah milik tanah di pejabat tanah. Sampel Pentadbir Tanah ini dipilih melalui kaedah pensampelan tidak rawak iaitu pensampelan bertujuan dari tiga buah daerah yang berbeza di salah sebuah negeri di Semenanjung Malaysia. Pentadbir tersebut diklasifikasikan kepada informan PTa, informan PTb dan informan PTc. Maklumat yang didapati dari informan-informan tersebut dianalisis menggunakan perisian Atlas.ti. Maklumat yang diperoleh membentuk tema dan sub-tema pemberian hibah. Berdasarkan tema dan sub-tema tersebut, kajian ini dapat mengenal pasti amalan pemberian hibah oleh ibu bapa kepada anak-anak.

\subsection{Dapatan Kajian}

Kajian ini mendapati terdapat dua tema utama dalam pemberian hak milik iaitu (1) peranan ibu bapa dan (2) kedudukan anak-anak. Bagi peranan ibu bapa, terdapat sembilan sub-tema iaitu (1.1) ibu bapa memberi tanpa balasan, (1.2) ibu bapa mengelakkan pembahagian pusaka, (1.3) ibu bapa membalas budi, (1.4) ibu bapa telah merancang pembahagian, (1.5) ibu bapa menunjukkan kasih sayang, (1.6) ibu bapa berhasrat untuk membantu anak-anak, (1.7) memudahkan anak-anak membuat pinjaman, (1.8) ibu bapa masih keadaan sihat dan (1.9) ibu bapa berhasrat anak-anak usahakan tanah tersebut. Manakala bagi tema kedudukan anak-anak, terdapat lapan sub-tema iaitu (2.1) anak membantu atau menjaga ibu bapa, (2.2) anak yang susah, (2.3) anak yang tinggal di kampung, (2.4) anak yang mempunyai ramai anak, (2.5) tahap 
pekerjaan anak yang rendah, (2.6) anak-anak berhasrat untuk membuat rumah, (2.7) anak-anak lain yang jarang pulang dan (2.8) anak-anak lain sudah berkerjaya.

Sub-tema 1.1, kajian ini mendapati hanya PTa sahaja yang menyatakan ibu bapa memberi tanpa balasan. Pemberian tanpa balasan ini boleh difahami sebagai pemberian percuma atau tanpa sebarang balasan seperti bayaran tertentu dari anak-anak. Manakala, bagi sub-tema 1.2, ketiga-tiga informan bersetuju bahawa tujuan ibu bapa memindahkan hak milik untuk mengelakkan pembahagian pusaka. Hal ini disebabkan sekiranya harta tersebut dibahagikan secara faraid, kemungkinan waris-waris yang jauh seperti bapa atau ibu saudara turut berhak ke atas sesuatu tanah dan menjadi lebih rumit kerana mengambil masa yang lama untuk menyelesaikan sesuatu kes tuntutan pusaka. Bagi 1.3 pula, hanya` PTb sahaja berpandangan pemindahan hak milik ini bertujuan untuk membalas budi anak tersebut. Hal ini disebabkan anak tersebut telah menjaga mereka. Sub-tema 1.4, kajian ini mendapati kesemua informan bersetuju bahawa ibu bapa telah merancang pembahagian harta mereka. Harta tersebut telah dirancang untuk diberikan kepada anak-anak tertentu dan tanah-tanah tertentu. Bagi menunjukkan kasih sayang (1.5), hanya PTa sahaja yang berpandangan pemberian pindah milik ini bertujuan berkenaan. Terdapat juga ibu bapa berhasrat untuk membantu anak-anak (1.6), namun hanya dinyatakan oleh PTc. Selain itu, terdapat juga ibu bapa memindahkan hak milik bagi memudahkan anak-anak membuat pinjaman (1.7) khususnya pinjaman perumahan. Hal ini disebabkan bagi tujuan mendapatkan pinjaman membina rumah, peminjam tersebut perlulah memiliki tanahnya sendiri. Kesihatan ibu bapa (1.8) juga perlu diberi perhatian, seperti yang dicadangkan oleh PTa. Tambahan lagi, PTc berpandangan, ibubapa memindahkan hak milik supaya anak-anak tersebut mengusahakan tanah berkenaan bagi tujuan pertanian (1.9).

Seterusnya, sub-tema 2.1, kajian ini mendapati ketiga-tiga informan berpandangan anak-anak membantu atau menjaga ibu bapa mereka menyebabkan ibu bapa menghibahkan hartanya kepada mereka. Menjaga ibu bapa termasuklah menjaga mereka semasa sakit dan menjaga makan minum mereka. Di samping itu, PTc berpandangan, ibubapa memindahkan hak milik tanah kepada anak yang susah bagi membantu anak tersebut (2.2), anak yang tinggal di kampung (2.3) dan anak yang mempunyai ramai anak (2.4). Pemindahan hak milik juga turut di pengaruhi oleh tahap pekerjaan anak yang rendah (2.5), di mana perkara ini dipersetujui oleh PTb dan PTc. Hal ini disebabkan kebanyakan penduduk di kawasan tersebut hanyalah bekerja kampung dan tidak bergaji tinggi. Perkara yang sama juga bagi sub-tema 2.6 di mana ketiga-tiga informan bersetuju bahawa tujuan ibu bapa memindah milik tanah disebabkan anakanak mereka berhasrat untuk membina rumah. Hal ini disebabkan kesukaran untuk mendapatkan pinjaman atau bantuan untuk membina rumah sekiranya seseorang itu, tidak memiliki tanah sendiri. Dari sudut yang lain, PTc percaya bahawa keadaan adik-beradik penerima hibah turut mempengaruhi ibu bapa dalam memindahkan hak milik tanah kepada anak-anak tertentu di mana anak-anak yang lain jarang pulang ke kampung (2.7) dan sudah berkerjaya (2.8)

\section{Jadual 1: Analisis Dapatan Temu bual}

\begin{tabular}{|c|c|c|c|}
\hline Tema & Sub-tema & Informan & Segmen temu bual \\
\hline \multirow[t]{3}{*}{$\begin{array}{l}\text { 1. Peranan } \\
\text { ibu bapa }\end{array}$} & 1.1 Ibu bapa memberi tanpa balasan. & PTa & $\begin{array}{l}\text { "Setakat ini, saya tidak jumpa lagi } \\
\text { ibu bapa membuat pindah milik ini, } \\
\text { anak beri bayaran." }\end{array}$ \\
\hline & \multirow[t]{2}{*}{$\begin{array}{l}1.2 \text { Ibu bapa mengelakkan pembahagian } \\
\text { pusaka. }\end{array}$} & PTa & $\begin{array}{l}\text { "Ada yang dia rasa mungkin timbul } \\
\text { masalah esok-esok selepas } \\
\text { meninggal apabila terpaksa buat } \\
\text { pusaka, maka ada yang ambil } \\
\text { inisiatif pindah awal-awal." }\end{array}$ \\
\hline & & PTb & $\begin{array}{l}\text { "Kebanyakan ibu bapa beri } \\
\text { semasa dia hidup itu, dia tidak } \\
\text { mahu menyusahkan anak- } \\
\text { anak apabila mereka sudah } \\
\text { meninggal dunia untuk buat }\end{array}$ \\
\hline
\end{tabular}




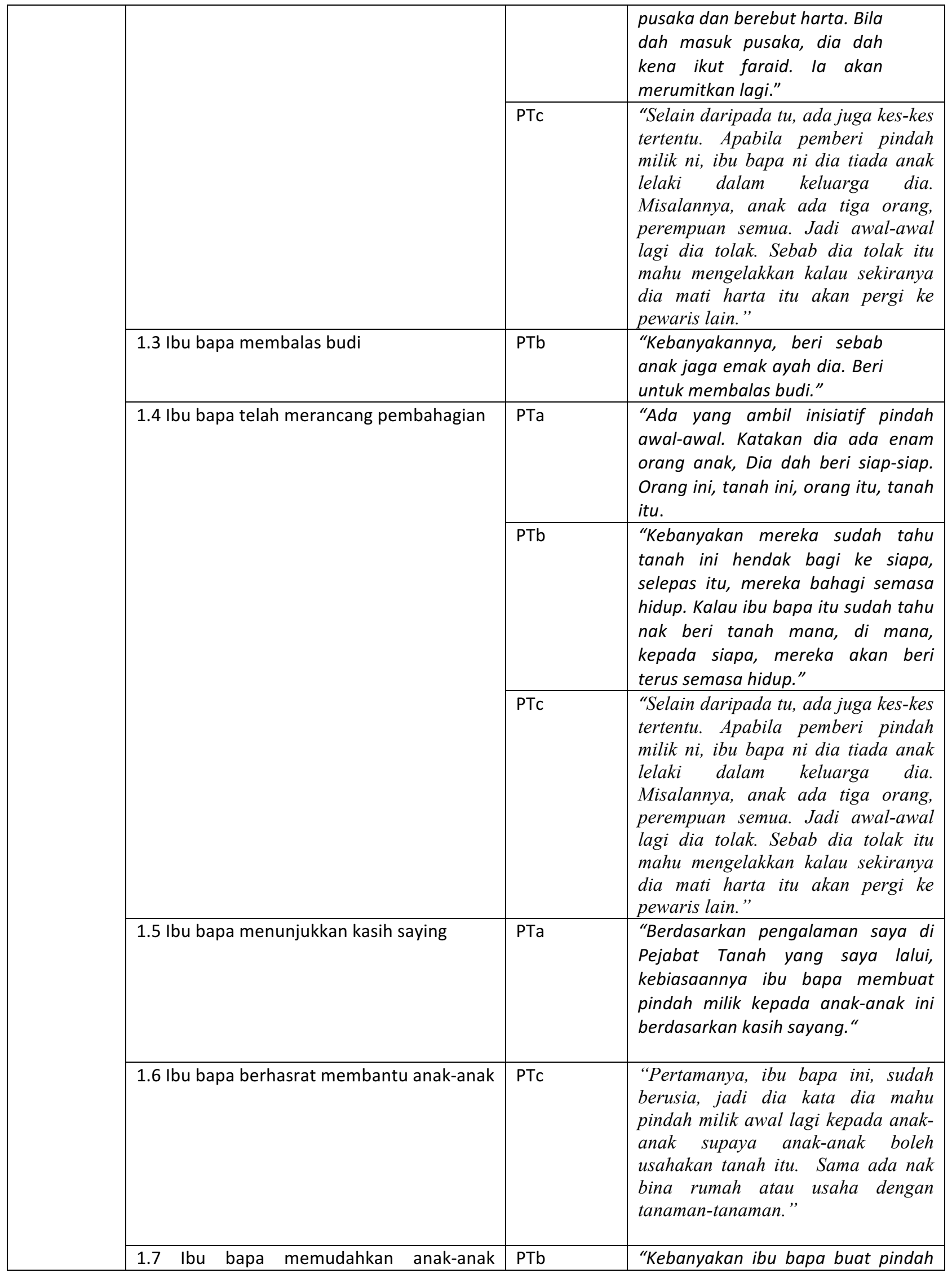


Mohd Khairy Kamarudin \& Nasrul HisyamNor Muhamad. / UMRAN - International Journal of Islamic and Civilizational Studies.Vol. 4, No 3-1 (2017)) 22-31

\begin{tabular}{|c|c|c|c|}
\hline & membuat pinjaman & & $\begin{array}{l}\text { milik, untuk anak-anak buat } \\
\text { pinjaman. Buat pinjaman } \\
\text { perumahan perlu dibuat atas tanah } \\
\text { tuannya sendiri, sebab itu perlu } \\
\text { tukarnama." }\end{array}$ \\
\hline & $1.8 \mathrm{lbu}$ bapa masih sihat & PTa & $\begin{array}{l}\text { "Sementara masih sihat dan masih } \\
\text { larat nak datang" }\end{array}$ \\
\hline & $\begin{array}{l}1.9 \text { Ibu bapa berhasrat anak mengusahakan } \\
\text { tanah }\end{array}$ & PTc & $\begin{array}{l}\text { "Ada persetujuan antara ibu bapa ni } \\
\text { sebagai pemberi pindah milik kepada } \\
\text { penerima iaitu anak-anak ni supaya } \\
\text { apabila dia beri, anak-anak } \\
\text { usahakan tanah tu, buat } \\
\text { pembangunan, sama ada buat } \\
\text { rumah, majukan dengan tanaman- } \\
\text { tanaman." }\end{array}$ \\
\hline \multirow{8}{*}{$\begin{array}{l}2 . \\
\text { Kedudukan } \\
\text { anak-anak }\end{array}$} & \multirow[t]{3}{*}{ 2.1 Anak membantu atau menjaga ibu bapa } & PTa & $\begin{array}{l}\text { "Mungkin anak dia banyak } \\
\text { membantu" }\end{array}$ \\
\hline & & PTb & $\begin{array}{l}\text { "Kebanyakan beri sebab anak jaga } \\
\text { emak ayah dia. Kalau jenis macam } \\
\text { orang kalau mereka ada } 10 \text { orang } \\
\text { anak, seorang yang jaga, dia akan } \\
\text { bagi seorang yang jaga." }\end{array}$ \\
\hline & & PTc & $\begin{array}{l}\text { "Jaga sakit, demam, makan dan } \\
\text { minum dia. Biasanya, ibu bagi ke } \\
\text { anak yang susah. Tambah pula } \\
\text { duduk jaga dia" }\end{array}$ \\
\hline & 2.2 Anak yang susah & PTc & "Yang susah ini lah yang jaganya." \\
\hline & 2.3 Anak yang tinggal di kampung & PTc & $\begin{array}{l}\text { "Kadang-kadang dia beri kepada } \\
\text { anak yang jaga dia, yang duduk } \\
\text { kampung." }\end{array}$ \\
\hline & 2.4 Anak yang mempunyai ramai anak & PTc & $\begin{array}{l}\text { "Ibu bapa kasihan kepada anak-anak } \\
\text { dia itu, maknanya anak-anak yang } \\
\text { lain, ada pekerjaan masing-masing. } \\
\text { Walaupun tidak kata kaya, tapi } \\
\text { masing-masing kerja kerajaan. Dia } \\
\text { boleh buat pinjaman, boleh beli } \\
\text { tanah. Anak yang ini, dia kerja } \\
\text { kampung. Anak-anak ramai." }\end{array}$ \\
\hline & \multirow[t]{2}{*}{ 2.5 Tahap pekerjaan anak yang rendah } & PTb & $\begin{array}{l}\text { "Macam kebanyakan penduduk di } \\
\text { sini kerja kampung, maka emak ayah } \\
\text { ada tanah tu, biasanya dia berilah } \\
\text { untuk membantu mereka di masa } \\
\text { hadapan mereka. Sebab di sini tidak } \\
\text { ramai yang kerja gaji mahal-mahal. } \\
\text { Biasanya kerja kampung." }\end{array}$ \\
\hline & & PTc & $\begin{array}{l}\text { "Ibu bapa kasihan kepada anak-anak } \\
\text { dia itu, maknanya anak-anak yang } \\
\text { lain, ada pekerjaan masing-masing. } \\
\text { Walaupun tidak kata kaya, tapi } \\
\text { masing-masing kerja kerajaan. Dia } \\
\text { boleh buat pinjaman, boleh beli } \\
\text { tanah. Anak yang ini, dia kerja }\end{array}$ \\
\hline
\end{tabular}


Mohd Khairy Kamarudin \& Nasrul HisyamNor Muhamad. / UMRAN - International Journal of Islamic and Civilizational Studies.Vol. 4, No 3-1 (2017)) 22-31

\begin{tabular}{|c|c|c|}
\hline & & kampung." \\
\hline \multirow[t]{3}{*}{$\begin{array}{l}2.6 \text { Anak-anak berhasrat untuk membuat } \\
\text { rumah }\end{array}$} & PTa & $\begin{array}{l}\text { "Pindah milik dibuat kepada anak } \\
\text { kerana anak itu tiada tanah untuk } \\
\text { buat rumah. Paling mudah, saya } \\
\text { buat contoh, kita ada Rumah Agihan } \\
\text { Zakat. Pemohon dikenakan syarat di } \\
\text { mana mesti ada tanah." }\end{array}$ \\
\hline & PTb & $\begin{array}{l}\text { "Buat pinjaman perumahan perlu } \\
\text { dibuat atas tanah tuannya sendiri, } \\
\text { sebab itu perlu tukar nama.", }\end{array}$ \\
\hline & PTc & $\begin{array}{l}\text { "Ada persetujuan antara ibu bapa ni } \\
\text { sebagai pemberi pindah milik kepada } \\
\text { penerima iaitu anak-anak ni supaya } \\
\text { apabila dia beri, anak-anak } \\
\text { usahakan tanah tu, buat } \\
\text { pembangunan, sama ada buat } \\
\text { rumah, majukan dengan tanaman- } \\
\text { tanaman." }\end{array}$ \\
\hline 2.7 Anak-anak yang lain jarang pulang & PTc & $\begin{array}{l}\text { "Lain-lain ada kerja. Masing-masing } \\
\text { dengan tanggungjawab masing- } \\
\text { masing. balikjarang-jarang." }\end{array}$ \\
\hline 2.8 Anak-anak yang lain sudah berkerjaya & PTc & $\begin{array}{l}\text { "Ibu bapa kasihan kepada anak-anak } \\
\text { dia itu, maknanya anak-anak yang } \\
\text { lain, ada pekerjaan masing-masing." }\end{array}$ \\
\hline
\end{tabular}

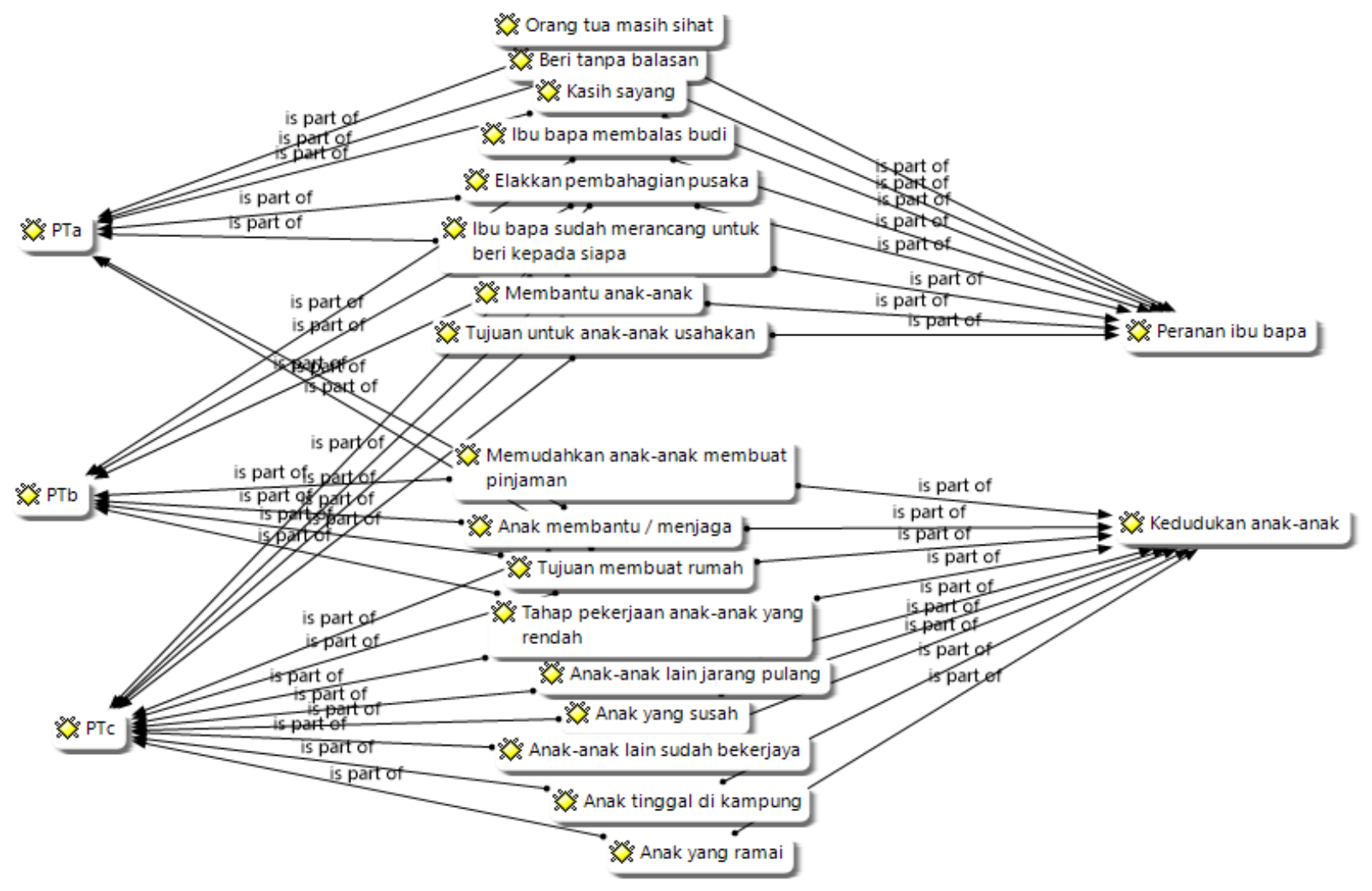




\subsection{Perbincangan Dan Kesimpulan}

Berdasarkan dapatan kajian, terdapat dua tema utama dalam pemberian hibah iaitu peranan ibu bapa dan kedudukan anak-anak. Ibu bapa sebagai pemilik harta berhak untuk menentukan kepada siapa harta perlu diberikan. Pemberian hibah ini dapat menunjukkan kasih sayang mereka kepada anak-anak. Pemberian tanpa balasan atau tanpa bayaran juga menunjukkan kesungguhan ibu bapa dalam membantu anak-anak mereka. Hal ini mengukuhkan lagi dapatan Albertini \& Radl, (2012), Barczyk \& Kredler, (2014) dan Wu \& Li, (2014). Bantuan pemberian tanah ini juga dapat membantu anak-anak mereka untuk mendapatkan pinjaman perumahan. Pinjaman ini dapat membantu pembangunan rumah baru dan lebih selesa kepada peminjam. Selaras dengan keperluan manusia iaitu memerlukan tempat untuk tinggal dan berteduh. Kajian ini mengukuhkan lagi wujudnya motif altruisme di mana ibu bapa yang mempunyai sifat altruistik lebih cenderung untuk membantu anak-anaknya yang kurang berkemampuan.

Selain itu, pemberian hibah semasa hidup dapat mengelakkan harta tersebut dituntut melalui pusaka. Hal ini disebabkan tuntutan pusaka mengambil masa yang panjang dan memerlukan kos. Dengan melakukan pindah milik ini, harta tersebut tidak lagi milik pemilik yang asal iaitu pemberi hibah. Maka, harta tersebut tidak lagi menjadi harta pusaka. Selain itu, terdapat juga ibu bapa menghibahkan harta mereka bagi menjamin anak-anak mereka mendapat hartanya tanpa menjadi hak milik waris-waris yang jauh. Perkara ini kebiasaannya terjadi kepada ibu bapa yang tidak mempunyai waris asabah iaitu wariswaris yang menghabiskan pusaka. Contohnya, ibu bapa yang hanya mempunyai seorang atau beberapa anak perempuan. Sekiranya harta tersebut tidak diagihkan semasa hidup, kemungkinan harta tersebut akan menjadi hak waris-waris yang jauh seperti adik-beradik simati atau baitul mal. Harta tersebut perlu diberikan kepada baitulmal jika si mati tidak mempunyai sebarang waris-waris asabah.

Kedudukan anak-anak juga perlu diambil kira di mana anak-anak tersebut tidak mempunyai kedudukan ekonomi yang kukuh mendorong ibu bapa untuk membantu mereka. Hal ini selaras dengan motif altruisme. Pada masa yang sama, wujudnya motif pertukaran di mana, anak-anak ini menjaga ibu bapa mereka semasa masih hidup. Berbanding anak-anak yang lain yang sudah berkerjaya dan tinggal jauh dari ibu bapa, anak-anak yang menerima hibah merupakan anak-anak yang tinggal di kampung bersama ibu bapa mereka atau tinggal berhampiran dengan ibu bapa. Selain itu, ibu bapa juga dapat menggalakkan anak tersebut untuk terus menjaga mereka seperti yang ditekankan oleh Raad \& Guedes, (2015).

Kesimpulannya, kajian ini mendapati peranan ibu bapa dan kedudukan anak-anak merupakan elemen penting dalam pengamalan pemberian hibah ibu bapa kepada anak-anak. Ibu bapa memainkan peranan mereka untuk membantu anak-anak yang memerlukan dan membalas budi anak-anak yang telah menjaga mereka. Kedudukan anak-anak pula memerlukan bantuan dari ibu bapa mereka khususnya untuk mendapatkan pinjaman pembinaan rumah. Pada masa yang sama, anak-anak menerima hibah disebabkan jasa mereka yang menjaga ibu bapa. Perkara ini juga menunjukkan wujudnya motif altruisme dan motif pertukaran dalam pemberian hibah.

\section{RUJUKAN}

Abdul Rashid, R., \& Ahmad, N. H. (2013). Pengurusan harta melalui hibah: Kepentingan dan manfaat dari pelbagai aspek untuk kemajuan ummah. Jurnal Hadhari, 5(1), 91-104.

Abdul Rashid, R., Hassan, S. A., \& Yaakub, N. I. (2013). A need for legal framework of gift inter vivos (hibah) in Malaysian estate planning. International Journal of Business, Economics and Law, 2(3), 29-31.

Abdul Rashid, R., Hassan, S. A., \& Yaakub, N. I. (2014). Gift inter vivos as an alternative method of property distribution for Muslim woman. The Social Sciences, 9(2), 126-128. 
Abdul Rashid, R., \& Yaakub, N. I. (2010). Hibah: Isu pindah milik dan pembatalan hibah hartanah di bawah Kanun Tanah Negara. Syariah Law Reports, 1, 14-29.

Albertini, M., \& Radl, J. (2012). Intergenerational transfers and social class: Inter-vivos transfers as means of status reproduction? Acta Sociologica, 55(2), 107-123.

Awang, A. B., \& Abd Rahman, A. A. (2014). Are parents free to bestow their wealth onto their children? A juristic discourse on equality and justice in hibah. Jurnal Syariah, 22(3), 407-426.

Aziz, I. H. (2016, March 29). RM60b harta umat Islam tidak dituntut. Berita Harian. Retrieved from http://www.bharian.com.my/node/138450

Barczyk, D., \& Kredler, M. (2014). A dynamic model of altruistically-motivated transfers. Review of Economic Dynamics, 17(2), 303-328.

Harta pusaka tidak dituntut mencecah angka RM60 bilion. (2016, February 1). Utusan Malaysia. Retrieved from http://www.utusan.com.my/berita/nasional/harta-pusaka-tidak-dituntut-mencecah-angka-rm60-bilion-1.185501

Hasbullah, M. H., \& Daud, M. Z. (2015). Perancangan pembahagian harta semasa hidup dalam Islam: Konsep dan kepentingannya. Global Journal Al-Thaqafah, 5(1), 119-131.

Kalmijn, M. (2013). How mothers allocate support among adult children: Evidence from a multiactor survey. Journals of Gerontology - Series B Psychological Sciences and Social Sciences, 68(2), 268-277.

Md Razak, M. I., Norizan, N. S., Ruslan, A. F., Mohd Nor, K., Sakarji, S. R., \& Ramlan, A. F. (2015). The awareness of hibah as a tool to reduce estate planning risk in Malaysia. International Journal of Economcis, Commerce and Management, 3(6), 1558-1565.

Mohd Yusof, Y., \& Ahmad, A. (2013). Hibah as an alternative mechanism in Muslims asset management: A study in Melaka Tengah. South East Asia Journal of Contemporary Business, Economics and Law, 3(3), 1-5.

Noordin, N., Shuib, A., Zainol, M. S., Azam, M., \& Adil, M. (2012). Review on issues and challenges in Islamic inheritance distribution in Malaysia. OIDA International Journal of Sustainable Development, 3(12), 27-38.

Nor Muhamad, N. H., \& Mat Hussain, N. (2014). Pembahagian harta pusaka Felda: Perspektif masyarakat Islam Felda Taib Andak. Jurnal Teknologi (Social Sciences), 66(1), 27-33.

Raad, R. J., \& Guedes, G. R. (2015). Private transfer choices under uncertainty in human capital. Revista Brasileira de Economia, 69(1), 105-124.

Scodellaro, C., Khlat, M., \& Jusot, F. (2012). Intergenerational financial transfers and health in a national sample from France. Social Science \& Medicine, 75(7), 1296-302.

Wong, E. S. (2013). Gender preference and transfers from parents to children: An inter-regional comparison. International Review of Applied Economics, 27(1), 61-80.

$\mathrm{Wu}, \mathrm{X} .$, \& Li, L. (2014). The motives of intergenerational transfer to the elderly parents in China: Consequences of high medical expenditure. Health Economics, 23(6), 631-652. 